\title{
European psychiatry: a force for the future
}

\author{
Robin M. Murray
}

European psychiatry has a distinguished history. Indeed, developments in the French and German speaking world at the end of the 19th century combined to establish our subject. Psychoanalysis emerged from the crucible of French and Viennese neurology while the basis of our modern system of classification was formulated in Kraepelin's clinic. Subsequently, Germany became the academic centre of psychiatry and remained so until the rise of the Nazis.

In the post-war period, with continental psychiatry in ruins, and America preoccupied with psychoanalysis, the focus of development moved to Scandinavia and to Britain. Indeed, in the late 1960s and early 1970s, British social psychiatry, then at its zenith, had an astonishing influence throughout the world via studies such as the US/UK diagnostic project, the World Health Organization cross cultural studies of schizophrenia, and research establishing the role of adverse life events in depression.

But where is the academic centre of psychiatry today; the answer is unquestionably the United States. In the late 1970s, under the dual stimuli of rapid advances in neuroscience and a newly operationalised classification system, American psychiatry revived (Murray, 1979). The American Psychiatric Association (APA) began marketing itself with typical American pzazz; indeed, its most potent symbols, the DSM-III and IV handbooks, now seem to rival McDonald's hamburgers in numbers sold around the world, and the annual APA conference has become part of the tourist scene attracting upwards of 20000 delegates, many from outside the USA.

The response of different European countries to this shift of power varied. Danish psychiatry accepted American research money but cleverly kept its own identity; British psychiatry pretended that nothing had changed, that Americans still couldn't diagnose schizophrenia, and tried to declare Britain a DSM-III free zone; in contrast, many younger German psychiatrists forgot their own phenomenological roots and adopted American practices; curiously, parts of French psychiatry were by now so out of date that its ideas, such as the rejection of the concept of schizophrenia, started becoming fashionable again. What none of us understood was that our countries were all too small to maintain an innovative tradition in isolation from each other.

\section{The Association of European \\ Psychiatrists}

However, on the continent this realisation was dawning, and in October 1983, the Association of European Psychiatrists (AEP) was founded by 12 French- and German-speaking psychiatrists; they included Berner from Vienna, Heimann from Tübingen. Hippius from Münich, Pull from Luxembourg and Singer from Strasbourg. Their intention was to create an association of psychiatrists from all European countries, following the political example set by the European Council and the European Community. Subsequently, the number of members has grown rapidly, and the AEP has become, in just a few years, the main forum for the exchange of scientific and clinical ideas in psychiatry in Western Europe; since the fall of communism it has expanded into Eastern Europe.

The AEP seeks to promote psychiatric research, to improve standards of psychiatric treatment across Europe, and to establish better teaching of psychiatry on a European scale. It has no wish to supplant the many excellent national organisations of psychiatrists but many issues now transcend national boundaries, and the AEP facilitates the dis- 
EDITORIAL

cussion of political issues affecting the practice of psychiatry in the different European countries.

The AEP has sections for the different subspecialities and interest groups (e.g. epidemiology and social psychiatry; forensic psychiatry, child psychiatry). It also encourages geographic diversity with an acknowledgement that different countries have different strengths. At present the AEP has a particular commitment to facilitate the development of psychiatry in the former Eastern countries, and their integration into the community of European psychiatrists.

\section{Combatting the paper drain}

It became apparent in the 1980s that the leading researchers in many European countries no longer sought to publish in their own national journals. They reasoned that since these journals are not in English, they are not widely read internationally. Furthermore, even in Britain, many researchers try to get their best work into an American journal because they think it will attract wider attention there.

To combat this alarming 'paper drain' across the Atlantic, the AEP established the journal European Psychiatry in 1988. The journal publishes - in English - papers on research or clinical innovations, and promotes the exchange of knowledge about developments in different European countries. European Psychiatry is already attracting papers of a higher standard than many other international journals; in a few more years we hope to stop, and even reverse, the paper drain!

\section{Scientific congresses}

Since its creation, the AEP has organised scientific meetings to enable European psychiatrists to communicate with each other and with psychiatrists from other continents, to debate different ideas, and to give European psychiatry a wider vision. These have proved highly successful, and have capitalised on the renewed vigour of European research, particularly in Germany, Sweden, and Holland.

The largest meetings are the AEP Congresses which take place every second year in the country of the current President of the AEP; the 1992 meeting in Barcelona attracted 1600 delegates, the 1994 meeting in Copenhagen 2500. In 1996 the 8th Congress of the AEP will take place jointly with the annual meeting of the Royal College between the 7th and 12th of July at the Queen Elizabeth II Centre in London. The theme will be "European Psychiatry: A Force for the Future".

As always, the British were slow to notice what was happening on the continent, and at the first AEP Congress that I attended there were only two other British participants. There have been fewer AEP members in Britain and Ireland than on the continent but there are now four of us on the Executive Committee (Ian Brockington, Stuart Montgomery, Tom Fahy, and myself). In this symbolic year of "le Chunnel", there is no longer any question that Britain is part of Europe. As it is with railways, so it is with psychiatry. The European psychiatric train is now moving and it is time to get on board!

\section{References}

MurRay, R. M. (1979) A Reappraisal of American Psychiatry. Lancet, 1, 225-258.

Association of European Psychiatrists (1994) Avallable from the AEP Secretariat, Strasbourg.

RobIN M. MURRAY, President, Association of European Psychiatrists

Anyone who would like to present a paper or poster at the Joint Congress, or anyone who would like further information about the AEP, should write to Professor $R$. Murray at the European Congress Secretariat, Royal College of Psychiatrists, 17 Belgrave Square, London SWIX 8PG 